Голуб В.М., Павленко А.Г., Чередніков О.М., Чуприна В.М. Державний науково-дослідний інститут випробувань і сертифікації озброєння та військової техніки

\title{
АНАЛІЗ МЕТОДИЧНИХ ПІДХОДІВ ДО ОЦІНЮВАННЯ НАДІЙНОСТІ АВІАЦІЙНОЇ ТЕХНІКИ ДЕРЖАВНӦ̈ АВІАЦІЇ ЗА ЕКСПЛУАТАЦИЙНИМИ ДАНИМИ
}

Розглянуто методичні підходи, щุо пропонуються для оцінювання надійності авіаційної техніки за експлуатаційними даними. Представлено результати оцінювання показників надійності вертольотів та їх функціональних систем за експериментальною методикою. Запропоновано напрями подальших досліджень 3 метою удосконалення даною методикою оцінювання надійності та підвищення безпеки польотів при переведенні військової авіаційної техніки на експлуатацію за технічним станом.

Ключові слова: авіаційна техніка, літальний апарат, надійність, показники, оцінка, пошкодження, несправність, відмова, інцицент, безпека польотів.

Вступ. Важливою задачею при переведенні військової авіаційної техніки (АТ) на експлуатацію за технічним станом, $є$ удосконалення системи збору, обробки та аналізу інформації про іiі технічний стан та надійність [1]. Від рівня експлуатаційної надійності, безпосередньо залежить безпека польотів повітряних суден (ПС), а саме - їх цілісність і життя людей, що знаходяться на борту ПС (екіпажів, особового складу та пасажирів).

Постановка проблеми. Важливим підгрунтям для вироблення рішень щодо підтримання справності та боєздатності АТ державної авіації $є$ інформація про іiї надійність та технічний стан, яка отримується в умовах експлуатації.

На теперішній час, існує декілька методичних підходів, рекомендованих для оцінювання надійності техніки за експлуатаційними даними, які викладені у різних нормативних та методичних документах. Зазначені підходи орієнтовані на виконання як однакових так і різних завдань, мають певні переваги й недоліки. Це, у свою чергу, обумовлює обмеження у використанні отриманих результатів та потребує вибору методичного підходу, який є найбільш пристосованим для вирішення поставлених завдань.

Аналіз останніх досліджень і публікацій. Різним аспектам оцінювання надійності технічних систем (у тому числі і військового призначення) присвячено ряд робіт закордонних та українських авторів $[1,4,5,8$, ]. Запропоновані, у більшості робіт, методи оцінювання показників надійності поділяють на дві групи: параметричні і непараметричні.

Дані методи рекомендовані до використання для встановлених державними стандартами планів спостережень (випробувань) на надійність [7, 11]. При цьому розглядаються також випадки використання як повних, так i цензурованих вибірок статистичних даних різного обсягу про відмови та несправності об'єктів.

Умови експлуатації АТ державної авіації характеризуються випадковими змінами наробітку (нальоту ПС) та числа об'єктів спостережень за періодами експлуатації. Тому, “реальний план” спостережень не відповідає жодному, встановленому стандартами.

До того ж, вирішення завдання контролю надійності АТ державної авіації в процесі експлуатації ускладнюється відсутністю обгрунтованих норм для відповідних показників [5].

Основним національним нормативним документом щодо методів оцінювання надійності техніки за експериментальними даними є ДСТУ 3004-95 [2]. Рекомендації даного стандарту передбачають визначення точкових та інтервальних оцінок показників надійності параметричними й непараметричними методами для різних планів спостережень (випробувань).

Для випадків, коли число відмов об'єктів спостережень протягом контрольного періоду менше 5, рекомендується визначати нижні границі довірчого інтервалу оцінки показника надійності. При цьому, умови спостережень мають бути ідентичними для всіх 
обраних об’єктів, що дуже складно забезпечити в процесі експлуатації АТ державної авіації. Щодо числа відмов однотипних виробів АТ, то воно, при відносно невеликому наробітку, за контрольний період (півріччя) дуже рідко дорівнює або перевищує 5.

Заслуговує особливої уваги підхід, реалізований у військовому стандарті США. Технічне обслуговування 3 контролем рівня надійності авіаційної техніки ВМС США регламентується військовим стандартом MIL-STD-882-2012 та відповідним керівництвом [6]. У цих документах, на підставі результатів детального аналізу ймовірних наслідків їх відмов, встановлені норми для показників надійності всіх типів виробів АТ, що знаходяться на озброєнні ВМС США, Ці норми в залежності від ступеня тяжкості наслідків відмов та вартості їх усунення, поділяються на чотири ступеня тяжкості, значення яких наведені в таблиці 1.

Таблиця 1

Матриця ризиків

\begin{tabular}{|l|c|}
\hline \multicolumn{1}{|c|}{ Ступені тяжкості наслідків відмов } & $\begin{array}{c}\text { Припустиме значення } \\
\text { имовірності відмови за } \\
1 \text { годину польоту ПС, } \\
1 / \text { год }\end{array}$ \\
\hline $\begin{array}{l}\text { Ступінь I - можливість загибелі або остаточної втрати } \\
\text { дієздатності членів екіпажу або інших осіб, руйнування, або } \\
\text { пошкодження літака, для відновлення якого потрібно } \\
\text { витратити більше, ніж 1 млн. доларів, або нанесення значної } \\
\text { шкоди навколишньому середовищу. }\end{array}$ & 0,000001 \\
\hline $\begin{array}{l}\text { Ступінь II - можливість пошкодження особового складу, } \\
\text { втрата здатності виконувати основні функції, пошкодження, } \\
\text { для відновлення якого потрібно витратити від 100 тис. до 1 } \\
\text { млн. доларів. }\end{array}$ & 0,00001 \\
\hline $\begin{array}{l}\text { Ступінь III - можливість завдання незначної шкоди здоров’ю } \\
\text { особового складу, пошкодження, для усунення якого потрібно } \\
\text { витратити від 10 тис. до 100 тис. доларів. }\end{array}$ & 0,0001 \\
\hline $\begin{array}{l}\text { Ступінь IV - пошкодження, для усунення якого потрібно } \\
\text { витратити менше, ніж 10 тис. доларів. }\end{array}$ & 0,001 \\
\hline
\end{tabular}

Слід відмітити ряд труднощів при практичному використанні “Матриці ризиків”.

По-перше, виникають значні труднощі при оцінці матеріальної шкоди, що виникає за окремою відмовою. До того $є$ випадки, коли таку шкоду зовсім важко визначити або ії практично немає .

По-друге, більш інформативними вважаються статистичні дані, за якими враховуються усі відмови і пошкодження, що виникають впродовж тривалого терміну часу кратному 100 і більше годин нальоту ПС.

Згідно рекомендацій Міжнародної організації цивільної авіації (ICAO - International Civil Aviation Organization) [9] існує іншій підхід, який полягає у широкому використанні, при оцінці ефективності забезпечення безпеки польотів ПС, “узагальненого” показника, який фактично враховує загальну кількість подій (відмов, інцидентів), що припадає на 100 год. польоту. Цей показник розраховується за наступною формулою:

$$
\mathrm{R}_{\mathrm{av}}=(\mathrm{n} / \mathrm{T}) \cdot \mathrm{D},
$$

де: $\mathrm{n}$ - загальна кількість авіаційних подій, од.;

$\mathrm{T}$ - загальний обсяг годин нальоту, год;

$\mathrm{D}=10^{2}-$ масштабний коефіцієнт. 
Метою статті $є$ аналіз можливостей використання результатів оцінювання надійності АТ, одержаних за допомогою різних методичних підходів.

Виклад основного матеріалу.

Оцінка реального рівня експлуатаційної надійності та безпеки польотів можлива, якщо відомі кількісні значення показників надійності.

Згідно [8] надійність АТ оцінюється такими показниками:

- наліт на відмову, яка приводить до невиконання бойового польотного завдання, $\mathrm{T}_{\text {інц }}($ год/неспр.);

- наліт на відмову та пошкодження, які виявились у польоті, $T_{n}$ (год/неспр.);

- наліт на відмову та пошкодження, які виявились у польоті та на землі, $T_{c}$ (год/неспр.).

На практиці ці показники невідомі, тому їх слід визначати на основі статистичних даних про відмови та пошкодження (несправності), що впливають на надійність експлуатації АТ. Статистика несправностей, яка отримана в процесі експлуатації ПС, має практичне значення, оскільки враховує вплив на стан АТ умов експлуатації та конструктивні особливості.

Дані, що наведені у статті, отримані за результатами аналізу донесень, які надсилають військові частини Повітряних Сил ЗС України до ДНДІ ВС ОВТ. Ці донесення складають військові частини згідно методичних рекомендацій [10].

Техніко-економічний та сутнісний аналіз вище визначених показників надійності дозволяє чітко визначити їх цільове призначення:

- кількісним показником, який дає оцінку рівню експлуатаційної надійності, слід вважати показник “наліт на несправність, яка виявилася у польоті та на землі (під час проведення технічного огляду) $\mathrm{T}_{\mathrm{c}}$ ”;

- кількісним показником, який дає оцінку рівню безпеки польотів, слід вважати показник “наліт на несправність, яка виявилася у польоті Т,";

- кількісним показником, який оцінює рівень виконання польотного завдання, є “наліт на інцидент, який приводить до невиконання польотного завдання, Тінц".

Проведений аналіз статистики несправностей, що зареєстровані на різних типах ПС 3 використанням вище зазначених показників, виявив наступні недоліки:

- відсутнє чітке ділення несправностей за різними типами ПС;

- відсутні конкретні деталі причин виникнення несправностей за конструктивновиробничими недоліками;

- при складанні рекламаційних актів часто не конкретизується авіаремонтне підприємство (завод) (АРЗ);

- відсутні дані щодо якості виконання гарантійних зобов'язань АРЗ;

- окремо не надається статистика несправностей на модернізовану АТ, яка прийнята на озброєння.

Основним обліковим документом про відмови та несправності АТ ЗС України $\epsilon$ картка обліку несправностей $(\mathrm{KOH})$, яка заповнюється в авіаційних частинах за єдиною формою. Згідно [10] Державний науково-дослідний інститут випробувань і сертифікації озброєння і військової техніки (ДНДІ ВС ОВТ) опрацьовує цю інформацію. На основі узагальнення та аналізу цієї інформації розробляється та видається один раз на рік Інформаційний випуск “Експлуатаційна надійність авіаційної техніки і безпека польотів”.

Оцінка рівня експлуатаційної надійності та безпеки польотів можлива, якщо відомі кількісні значення показників надійності. На практиці кількісні значення показників 
надійності уточнюються на основі статистичних даних про виявлені відмови. Визначення показників експлуатаційної надійності та безпеки польотів за статистичними даними, отриманими в процесі експлуатації ПС, $\epsilon$ важливим, оскільки враховує вплив умов та режимів роботи на стан АТ, їх конструктивного виконання та правил експлуатації.

Інженерний аналіз експлуатаційної надійності АТ проводиться на основі узагальнення практичного досвіду збереження льотної придатності парку ПС України. Головною метою інженерного аналізу є визначення причин відмов, ступеня їх впливу на працездатність виробів та систем, а також наслідків, до яких вони можуть призвести. Результатом аналізу повинні бути як конкретні пропозиції та заходи щодо попередження відмов АТ, так i кількісні значення показників експлуатаційної надійності. Отримані, у результаті обробки інформації, значення показників надійності за період експлуатації порівнюються 3 відповідними значеннями показників за попередні періоди.

Такий підхід дозволяє здійснити якісну оцінку рівня надійності АТ по відношенню до попередніх періодів експлуатації. При цьому статистичні дані про відмови та несправності ПС військового призначення отримуються при нестабільних умовах спостережень, що значно впливає на точність та достовірність оцінки.

Для оцінки надійності об'єктів АТ використовуються встановлені стандартами показники, що приведені у [8]. Відомо, що одиничні показники надійності (наприклад, ремонтопридатність) характеризують тільки одну із властивостей технічного об'єкту, в той час як комплексні показники характеризують декілька властивостей, і використовуватися у якості основних для оцінки ефективності таких складних об'єктів, як ПС та його функціональних систем.

Тому, важливою проблемою підтримки високого технічного стану АТ є оцінка реального рівня експлуатаційної надійності та безпеки польотів.

У даній статті розглядаються методичні підходи вирішення цієї проблеми на прикладі вертольотів.

Даний підхід складається з наступних етапів:

- групування статистики несправностей за системами відповідного виду спеціальності: “Літак, вертоліт і двигун” (ЛВіД) “авіаційне озброєння” (АОз), “авіаційне обладнання” (АО), “радіоелектронне обладнання” (PEO), “авіаційний прицільнонавігаційний комплекс" (АПНК); $\mathrm{T}^{\mathrm{A \Pi HK}}$

- розрахунок по кожній спеціальності показників надійності: $\mathrm{T}^{\text {ЛВід }}, \mathrm{T}^{\mathrm{AO} 3}, \mathrm{~T}^{\mathrm{PEO}}, \mathrm{T}^{\mathrm{AO}}$,

- розподіл несправностей за системами та підсистемами кожної спеціальності та визначення найменш надійних систем і причин їхньої недостатньої надійності;

- розподіл несправностей за видами підготовки АТ до польоту за кожною спеціальністю та визначення ефективності проведення цих робіт;

- розрахунок середніх значень показників надійності для різних типів ПС;

- групування статистики несправностей за основними причинами їх появи: практичної діяльності льотного складу (ЛС), інженерно-технічного складу (ITC), впливу конструктивновиробничих недоліків (КВН) та неякісного ремонту (НР).

Показник надійності - кількісна характеристика однієї чи декількох із тих властивостей, які в сукупності складають надійність ПС як об'єкта експлуатації, головними складовими якої $є$ експлуатаційна надійність і безпека польотів.

На рисунку 1 представлена структурна схема методичного підходу до аналізу і оцінки рівня надійності ПС. 
Збірник наукових праць Державного науково-дослідного інституту випробувань і сертифікачії озброєння та військової техніки. 2019. Вип. № 2

ISSN 2706-7386

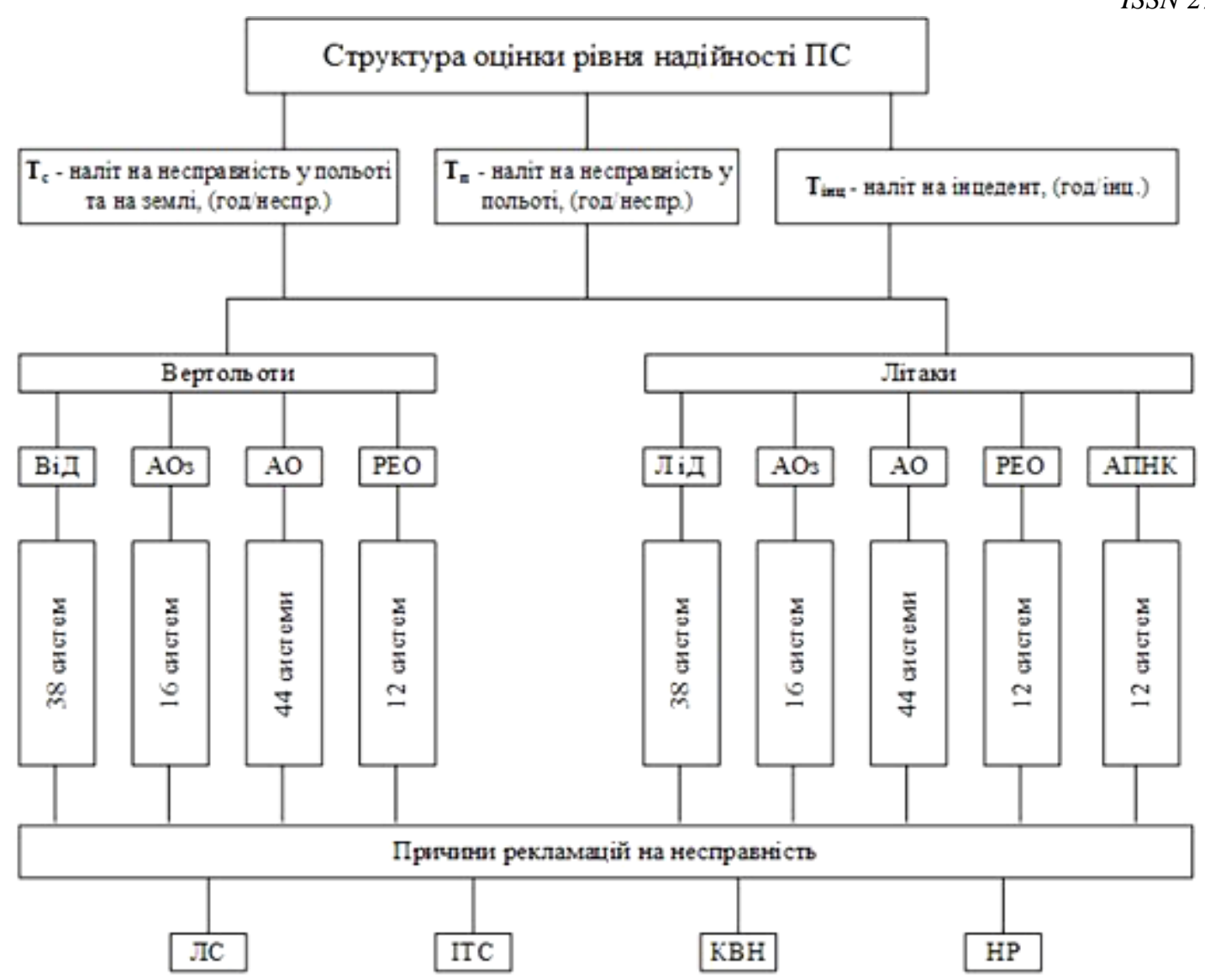

Рис.1 - Структура оцінки рівня надійності ПС

За статистичними даними експлуатації вертольотів у військових частин за спеціальністю ВіД за 2018 рік проведений порівняльний аналіз та підраховані показники, які наведені в таблиці 2 та відображені на рисунку 2.

Таблиця 2

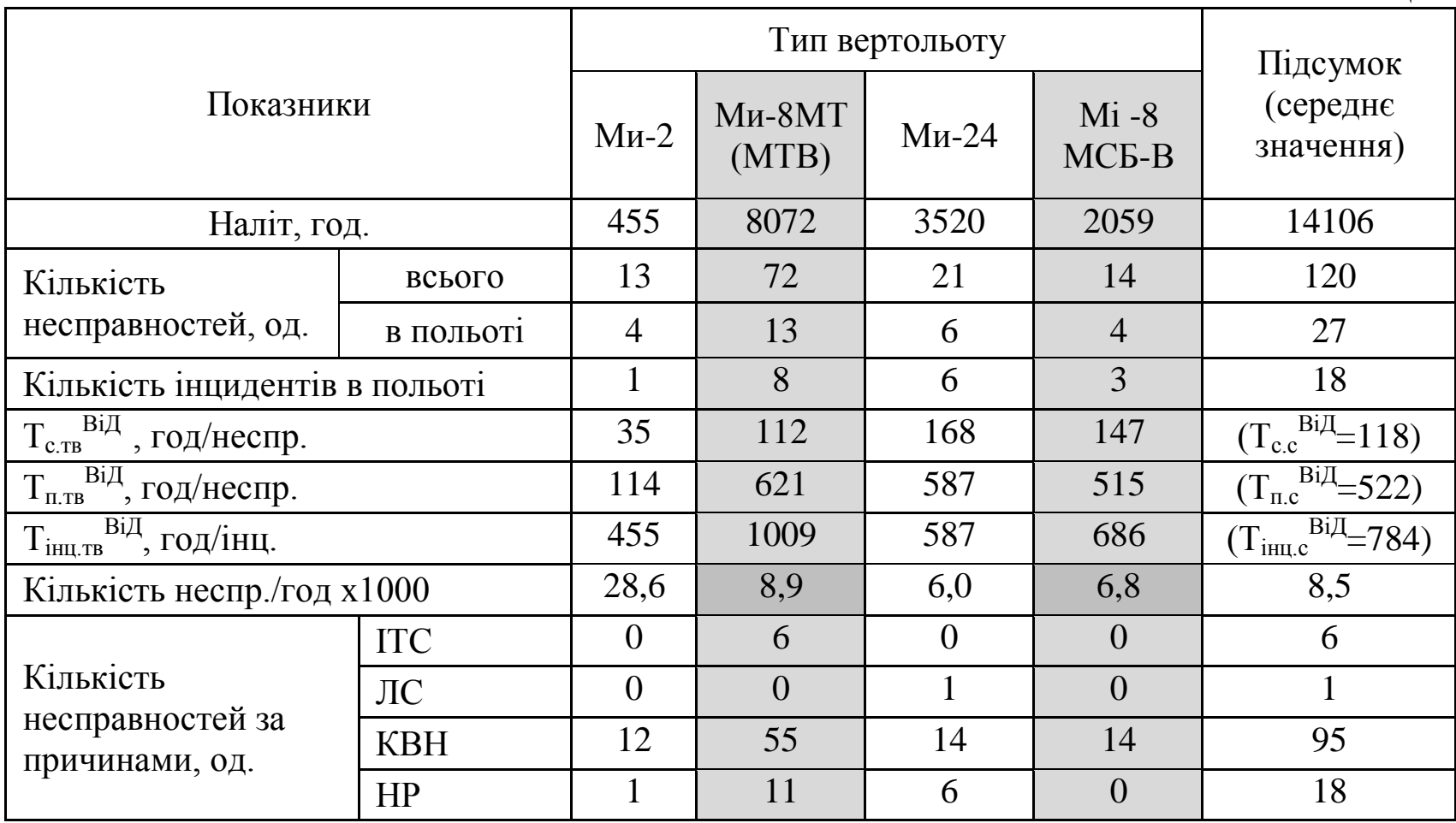

Статистика несправностей та показники надійності 
Збірник наукових праць Державного науково-дослідного інституту випробувань і сертифікації озброєння та військової техніки. 2019. Вип. № 2

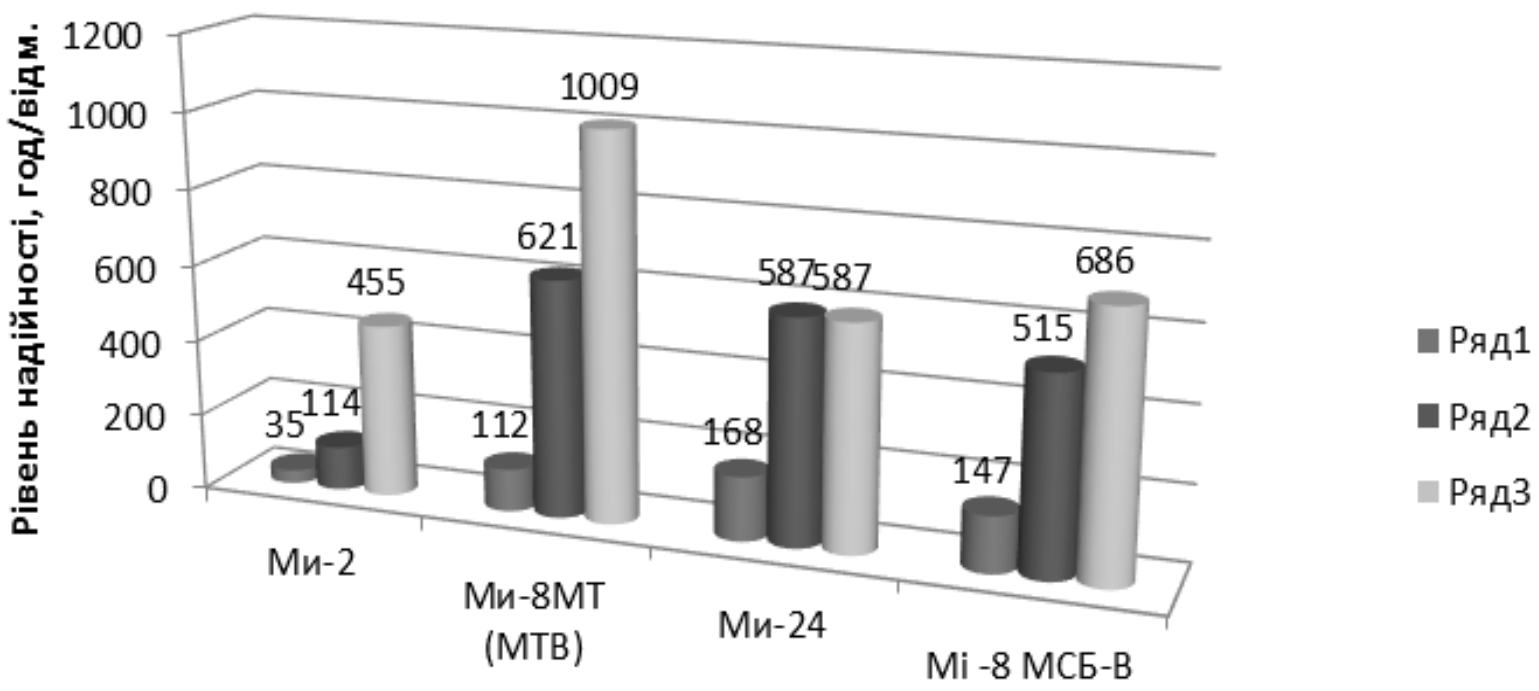

Тип вертольота

Ряд 1 - - Рівень експлуатаційної надійності вертольотів

Ряд2 - - Рівень безпеки польотів вертольотів

Ряд3 - - Рівень виконання бойового польотного завдання вертольотів

Рис.2 - Порівняння показників надійності для вертольотів

За результатами аналізу даних таблиці 2 та рисунку 2 отримані наступні висновки:

За показником - наліт на несправність, що виявлена в польоті та на землі $\mathrm{T}_{\text {с.тв }}$ Від, який характеризує рівень експлуатаційної надійності конкретного типу вертольоту:

- найбільшу експлуатаційну надійність систем за спеціальністю ВіД мають вертольоти типу Ми-24, на другому місці вертольоти типу Мі-8МСБ-В;

- середнє значення показника експлуатаційної надійності $\mathrm{T}_{\text {с.с. }}$ Від для систем спеціальності ВіД складає 118 год/неспр.

За показником - наліт на несправність, що виявлена в польоті $\mathrm{T}_{\text {п.тв }}$ від який характеризує безпеку польотів конкретного типу вертольоту:

- найбільший рівень безпеки польотів забезпечують системи за спеціальністю ВіД вертольотів типу Ми-8МТ(МТВ) на другому місці вертольоти типу Ми-24;

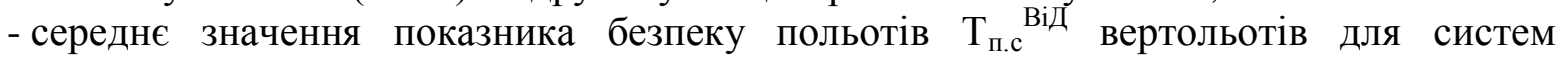
спеціальності ВіД складає 522 год.

Для порівняння рівня надійності окремих систем за спеціальністю ВіД проаналізовані дані наведені на рисунку 3.

За результатами аналізу (рис.3) найменш надійними системами слід вважати:

- для Ми-8МТ(МТВ) - паливна система (код 028) - на долю якої припадає 27,8\% від загальної кількості виявлених несправностей на даному типі вертольотів;

- для Мі-8МСБ-В - трансмісія вертольоту (код 084) - 28,6\%;

- для Ми-2 - гвинти вертольоту (код 65) - 30,7\%.

При цьому більше ніж 60\% від загальної кількості виявлених несправностей припадає на вертольоти типу Ми-8МТ(МТВ).

Використовуючи рекомендації ICAO щодо показника рівня аварійності та дані таблиці 1, виконано розрахунок “узагальненого" показника за формулою (1) для вертольотів типу Мі-8МСБ-В та Ми-8МТ(МТВ).

Отримані наступні результати розрахунків:

- для Мi-8МСБ-В $\mathrm{R}_{\mathrm{av}}=(14$ / 2059) х $100=0,680$ (відм. на 100 год нальоту);

- для Ми-8МТ(МТВ) $\mathrm{R}_{\mathrm{av}}=(72$ / 8072) х $100=0,892$ (відм. на 100 год нальоту). 


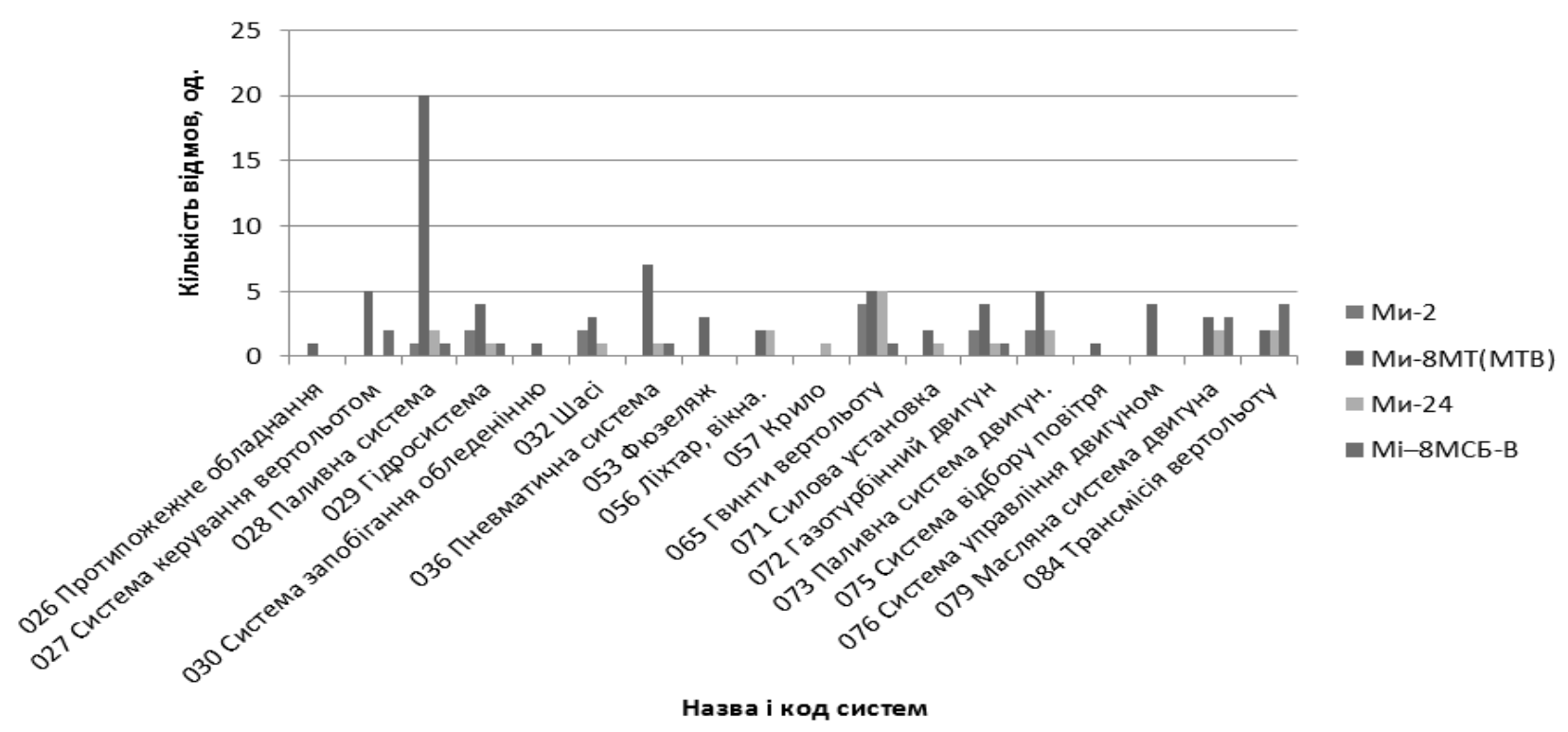

Рис.3 - Порівняння рівня надійності окремих систем за спеціальністю ВіД

Порівняльний аналіз показав, що показник ефективності забезпечення безпеки польотів вертольотів типу Мі-8МСБ-В перевищує цей показник вертольоту типу Ми-8МТ(МТВ) на 23,77\%.

Якщо визначити “узагальнений” показник рівня аварійності для створеного в Україні за роки незалежності сучасного середнього багатоцільового вертольоту типу Мі-8МСБ-В за військовим стандартом MIL-STD-882-2012, то цей показник відповідає Ступіню IV (див. табл.1).

Основні недоліки, що виявлені в процесі експлуатації вертольотів за спеціальністю ВіД у 2018 році, наступні:

- недостатня укомплектованість технічних аптечок та ремонтного фонду агрегатами, виробами та комплектуючими;

- недостатня якість капітального ремонту призводить до руйнування гумотехнічних виробів, шлангів систем, гумових кілець агрегатів повітряної системи, манжет шарнірів втулок несучого гвинта, графітових ущільнень масляної системи двигуна;

- значна кількість відмов на АТ пов'язана $з$ довготривалою експлуатацією агрегатів несучої системи вертольота, що призводить до виникнення усталосних тріщин та руйнування деталей кріплення.

Для підвищення надійності функціонування систем за спеціальністю Від пропонується: виробів;

- при виконанні капітального ремонту АТ підвищити вимоги до якості гумотехнічних

- замінити малонадійні, фізично застарілі підвісні паливні баки на нові сучасні та постійно забезпечувати необхідними якісними паливно-мастильними матеріалами;

- передбачити наявність у техніко-експлуатаційної частини АТ (ТЕЧ АТ) дефіцитних агрегатів (ТВ3-117ВМ, лопаті несучого гвинта, лопаті рульового гвинта, головний редуктор ВР-14), що мають запас міжремонтного ресурсу.

\section{Висновки.}

1. Проведений аналіз проблеми забезпечення надійності авіаційної техніки та безпеки польотів показав, що для достовірної оцінки рівня надійності АТ і забезпечення безпеки польотів необхідно проводити постійний моніторинг несправностей ПС, їх систем та підсистем і збирати статистику за типами ПС.

2. Реалізація розробленого методичного підходу проведення порівняльного аналізу рівня надійності різних типів вертольотів дає можливість конкретизувати причини та 


\section{Збірник наукових прачь Державного науково-дослідного інституту випробувань і сертифікачї̈ озброєння та військової техніки. 2019. Вип. № 2}

ISSN 2706-7386

наслідки впливу виявлених несправностей за окремими спеціальностями та системами, що забезпечують безперебійне функціонування АТ в процесі її експлуатації.

\section{СПИСОК ЛІТЕРАТУРИ}

1. Шатов В.А. Актуальні завдання управління процесом експлуатації авіаційної техніки Збройних Сил України: тези доповідей та виступів / В.А. Шатов, С.В. Пащенко // Науковопрактична конференція “Актуальні проблеми розвитку авіаційної техніки”. - К.: ДНДІА, 2010. - C. 117.

2. Надійність техніки. Методи оцінки показників надійності за експериментальними даними: ДСТУ 3004:95. - [Чинний від 1995-01-25]. - К.: Держстандарт України, 1994. - 124 с. - (Державний стандарт України).

3. Надійність техніки. Моделі відмов: ДСТУ 3433:96. - [Чинний від 1997-12-05]. - К.: Держстандарт України, 1996.- 46 с. - (Державний стандарт України).

4. Смирнов Н.Н. Обслуживание и ремонт авиационной техники по состоянию / Н.Н.Смирнов, А.А Ицкович. - М.: Транспорт, 1987. - 277 с.

5. Павленко А.Г. Підхід до розробки способу нормування надійності обладнання військових літальних апаратів для реалізації стратегії технічного обслуговування за станом: тези доповідей та виступів. / А.Г. Павленко, В.І. Соловйов, В.В. Хижун // Науковопрактична конференція “Актуальні проблеми розвитку авіаційної техніки”. - К.: ДНДІА, 2009. - C. 85.

6. Guidelines for the Naval Aviation Reliability Centered Maintenance Process: NAVAIR 00-25-403. - US Department of Defense Publications. Philadelphia, Pennsylvania, 2005. $-195 \mathrm{p}$.

7. Соловйов B.I. Аналіз можливих шляхів вирішення задачі нормування надійності обладнання військових літальних апаратів для реалізації стратегії технічного обслуговування за станом / В.І.Соловйов, А.Г.Павленко, С.А.Копашинський // Труди університету. - К.: НУОУ, 2010. - №1 (91). - С. 139-143.

8. Голуб В.М. До питання аналізу експлуатаційної надійності та безпеки польотів повітряних суден. "Математичне та імітаційне моделювання систем МОДС 2018": тези доповідей . / В.М. Голуб, М.М. Жданюк, В.Т. Бояров, В.М. Чуприна, Е.Ф. Сідін // Тринадцята міжнародна науково практична конференція. До 100 - річчя Національної академії наук України. Київ-Чернігів-Жукін, 25-29 червня 2018 р. - Чернігів: ЧНТУ, 2018. - С.379-381.

9. Гончаренко Є.В. Щодо застосування концепції прийнятого рівня забезпечення безпеки польотів в суб'єктах авіаційної діяльності державної авіації: тези доповідей. / Є.В. Гончаренко, О.Р. Мартинюк // Збірник тез XIX науково-технічної конференції, 05-06 вересня 2019 р. - Чернігів: ДНДІ ВС ОВТ, 2019. - С. 89.

10. Методичні рекомендації державної авіації щодо збору, аналізу і подання інформації про несправності авіаційної техніки (МРДА-02/16) [Текст]. - Київ:, 2016 -104 с.

11. Пащенко С.В. Методологічні аспекти визначення фактичного ресурсу авіаційної техніки: тези доповідей та виступів. / С.В. Пащенко, Ю.О. Манулін // Міжнародна науковотехнічна конференція “Актуальні проблеми розвитку авіаційної техніки”. - К.: ДНДІА, 2019. - C. 104.

\section{Голуб Володимир Маркович}

кандидат технічних наук, доцент, провідний науковий співробітник Державного науководослідного інституту випробувань i сертифікації озброєння та військової техніки, Чернігів, Україна https://orcid.org/0000-0002-7796-3054 $+38097-684-64-51$

\section{Volodymyr Golub}

Candidate of Technical Sciences, Associate Professor, Lead Researcher of State Scientific Research Institute of Armament and Military Equipment Testing and Certification, Chernihiv, Ukraine https://orcid.org/0000-0002-7796-3054 +38097-684-64-51 


\section{Павленко Анатолій Григорович}

кандидат технічних наук, старший науковий співробітник, начальник науковоорганізаційного відділу Державного науководослідного інституту випробувань i сертифікації озброєння та військової техніки, Чернігів, Україна

https://orcid.org/0000-0001-6341-8381

+38093-698-59-67

\section{Чередніков Олег Миколайович}

кандидат технічних наук, доцент, старший науковий співробітник Державного науководослідного інституту випробувань i сертифікації озброєння та військової техніки, Чернігів, Україна

https://orcid.org/0000-0003-1258-590X

+38050-297-83-98

\section{Чуприна Володимир Михайлович}

доктор технічних наук, доцент, провідний науковий співробітник Державного науководослідного інституту випробувань i сертифікації озброєння та військової техніки, Чернігів, Україна https://orcid.org/0000-0003-4886-090X +38068-131-66-06

\section{Anatolii Pavlenko}

Candidate of Technical Sciences, Senior Researcher, Chief of Section of State Scientific Research Institute of Armament and Military Equipment Testing and Certification, Chernihiv, Ukraine

https://orcid.org/0000-0001-6341-8381 +38093-698-59-67

\section{Oleg Cherednikov}

Candidate of Technical Sciences, Associate Professor, Senior Researcher of State Scientific Research Institute of Armament and Military Equipment Testing and Certification, Chernihiv, Ukraine

https://orcid.org/0000-0003-1258-590X

+38050-297-83-98

\section{Volodymyr Chupryna}

Doctor of Technical Sciences, Associate Professor, Lead Researcher of State Scientific Research Institute of Armament and Military Equipment Testing and Certification, Chernihiv, Ukraine https://orcid.org/0000-0003-4886-090X $+38068-131-66-06$

\section{ANALYSIS OF METHODICAL APPROACHES TO ASSESSING THE RELIABILITY OF STATE AVIATION EQIPMENT ON OPERATIONAL DATA V. Golub, A. Pavlenko, O. Cherednikov, V. Chupryna}

The article describes the methodological approaches that are offered by national and international standards as well as departmental normative and methodological documents for the assessment of the reliability of the aviation equipment of operational data. The urgency of the task of solving the problem of estimation of level of operational reliability and safety of military aircraft is increasing along with the need to adapt existing techniques to the requirements of NATO standards.

Modern conditions of operation of aircraft of state aviation are characterized by random changes of flying hours and the number of objects of observation for periods of operation. Therefore, the "real" plan of observation on the defect record sheet fails to meet any of the plans prescribed by the standards. At the same time, the solution to the problem of monitoring the reliability of state aviation aircraft in the process of operational service is hindered by the lack of reasonable standards for the respective indicators of reliability of military aircraft of the state aviation operational data.

The results of evaluation of the reliability of the helicopters and their functional systems based on the experimental methodology. On the basis of generalization and analysis of this information is produced and published once a year newscast "The operational reliability of aviation equipment and safety".

The analysis of the problem of ensuring the reliability of aviation equipment and flight safety has shown that reliable estimation of the real level of reliability and flight safety is necessary to conduct constant monitoring of malfunctions of aircraft systems and subsystems and to collect statistics on types of aircraft. In order to improve this method of assessing the reliability and improving the flight safety in the conversion of military aviation equipment to service by technical condition, directions for further research are proposed.

Keywords: aviation equipment, aircraft, reliability, performance, evaluation, damage, malfunction, failure, incident, flight safety. 